\title{
Frequency of AIDS in District Dera Ghazi Khan
}

\author{
Ayaz Ahmad* \\ Assistant Professor, Biology Govt Degree College, Pakistan
}

Submission: January 26, 2019; Published: March 15, 2019

*Corresponding author: Ayaz Ahmad, Assistant Professor, Biology Govt Degree College, Block No 17, Dera Ghazi Khan, Pakistan

Abstract

According to the survey conducted in Dera Ghazi Khan district in 2017, there are around 20,000 HIV/AIDS patients in south Punjab districts. Dera Ghazi Khan alone has 1,650 patients registered with the Punjab AIDS Control Programme and, the number of unregistered patients in the district may be over 9,000. There has been a 40 per cent increase in the number of AIDS patients reported in 2017, The reason behind the increase was a lack of awareness. There are more than 200 HIV/AIDS patients living in Dera Ghazi Khan's rural areas like Sakhi Sarwar, Kot Mubarak, Kaala, Saddaruddin, Yaaru Khosa and the tribal belt.The situation is very alarming.

Keywords: AIDS; HIV; Patients; Awareness; Breast feeding; Contaminated syringes; Human immuno virus; Drug addicts; Disease

\section{Introduction}

AIDS is an infectious disease, spread through free sexual contact, breast feeding, use of contaminated syringes etc. AIDS is caused by HIV (Human Immuno Virus). Dera Ghazi khan is a district in south Punjab. In this district AIDS patients are increasing at high ratios due to lack of awareness in the peoples of this remote area of Punjab, Pakistan [1].

\section{Material and Method}

A survey was conducted in 2017, in which information were collected from the resident areas of the patients. Information were also Collected from the AIDS control centre in Dera Ghazi Khan District Hospital [2].

\section{Causes of proliferation of AIDS in D.G. Khan}

Peoples who return to Pakistan from the gulf and foreign countries, quacks, drug addicts and reuse of affected syringes, are the major causes for the spread. The Patients said that they have been affected by HIV/AIDs while they were in foreign countries. They revealed that they have been deported after diagnosis of the disease.

\section{Results and Discussion}

In Sakhi Sarwar There were 45 patients, 48 in Kot Mubarak, 8 in Kaala, 12 in shah Saddaruddin, 10 in Yaaru Khosa and 20 in the tribal belt. The centre for the screening of HIV /AIDS patient was constructed in Dera Ghazi Khan in 2006. It has the largest number of registered patients in the Punjab. While sources revealed that the numbers of non-registered cases are more than 8,000 in Dera Gazi Khan. At least 45\% women are included in this ratio. The surging figures have been caused due to lack of awareness among people. Sources from Aids Control Center, said the number of patients suffering from HIV/AIDS is steadily growing in South Punjab, especially in Dera Gazi Khan and its adjoining areas [3].

During one year, the numbers of reported cases have increased to $40 \%$. A total of 1,900 cases were registered till December 31, 2017 and till date, the numbers have reached to 2,798 . Accordingly, there are more than 2,200 males, 508 females, 90 children and transgender people are included in this figure. At the same time, the details of the patients are kept secret. In a shocking disclosure, HIV/AIDS infection cases are on the rise in Dera Ghazi Khan District as 600 people have died due to lack of treatment facilities. More than 2,798 such cases have been reported in different health facilities in the region this year, and their data is saved for future correspondence. It has been revealed that 91 females infected with the disease gave birth to babies during treatment and of them, only one baby has the AIDS virus [4].

\section{References}

1. (2005) CIA the World Factbook. Pakistan.

2. (2005) The World Health Report 2005. Pakistan.

3. Amir Latif (2006) "Pakistan sitting on a ticking AIDS bomb". Pakistan Tribune.

4. (2007) "UNAIDS Epidemic update 2007". 
(C) This work is licensed under Creative

(C) Commons Attribution 4.0 Licens

BY DOI: 10.19080/CRDOJ.2019.10.555780
Your next submission with Juniper Publishers

will reach you the below assets

- Quality Editorial service

- Swift Peer Review

- Reprints availability

- E-prints Service

- Manuscript Podcast for convenient understanding

- Global attainment for your research

- Manuscript accessibility in different formats

( Pdf, E-pub, Full Text, Audio)

- Unceasing customer service

Track the below URL for one-step submission https://juniperpublishers.com/online-submission.php 